\title{
Fungal Biofilms: Targets for the Development of Novel Strategies in Plant Disease Management
}

OPEN ACCESS

Edited by:

Sabine Fillinger,

Institut National de la Recherche

Agronomique (INRA), France

Reviewed by:

Sonia Rozental,

Federal University of Rio de Janeiro,

Brazi

Michael Harding,

Alberta Ministry of Agriculture and Forestry, Canada

*Correspondence:

Andrea Kunova

andrea.kunova@unimi.it

Specialty section: This article was submitted to Antimicrobials, Resistance and Chemotherapy,

a section of the journal

Frontiers in Microbiology

Received: 14 September 2016 Accepted: 30 March 2017 Published: 13 April 2017

Citation:

Villa F, Cappitelli F, Cortesi P and Kunova A (2017) Fungal Biofilms: Targets for the Development of Novel

Strategies in Plant Disease

Management. Front. Microbiol. 8:654.

doi: 10.3389/fmicb.2017.00654

\author{
Federica Villa, Francesca Cappitelli, Paolo Cortesi and Andrea Kunova* \\ Department of Food, Environmental and Nutritional Sciences, Università degli Studi di Milano, Milan, Italy
}

The global food supply has been facing increasing challenges during the first decades of the $21^{\text {st }}$ century. Disease in plants is an important constraint to worldwide crop production, accounting for $20-40 \%$ of its annual harvest loss. Although the use of resistant varieties, good water management and agronomic practices are valid management tools in counteracting plant diseases, there are still many pathosystems where fungicides are widely used for disease management. However, restrictive regulations and increasing concern regarding the risk to human health and the environment, along with the incidence of fungicide resistance, have discouraged their use and have prompted for a search for new efficient, ecologically friendly and sustainable disease management strategies. The recent evidence of biofilm formation by fungal phytopathogens provides the scientific framework for designing and adapting methods and concepts developed by biofilm research that could be integrated in IPM practices. In this perspective paper, we provide evidence to support the view that the biofilm lifestyle plays a critical role in the pathogenesis of plant diseases. We describe the main factors limiting the durability of single-site fungicides, and we assemble the current knowledge on pesticide resistance in the specific context of the biofilm lifestyle. Finally, we illustrate the potential of antibiofilm compounds at sub-lethal concentrations for the development of an innovative, eco-sustainable strategy to counteract phytopathogenic fungi. Such fungicide-free solutions will be instrumental in reducing disease severity, and will permit more prudent use of fungicides decreasing thus the selection of resistant forms and safeguarding the environment.

Keywords: fungal biofilm, non-fungicide management practices, biofilm resistance, bioactive natural compounds, non-biocidal antibiofilm compounds

\section{INTRODUCTION}

Ensuring global food security is one of the greatest challenges facing humanity in the $21^{\text {st }}$ century. The intensification of world agriculture has to happen in an era, when climate is becoming less predictable, fossil fuel dependency needs to be cut, and cropland and water resources are shrinking or deteriorating (Alexandratos and Bruinsma, 2012; Popp et al., 2013). As a result, it is unclear how the growing demand for food can be achieved sustainably. Furthermore, the crops are constantly threatened by pests, pathogens and weeds. Indeed, several studies have estimated that, on average, $20-40 \%$ of the potential worldwide crop yield is lost each year due to pests and diseases (Oerke and Dehne, 2004; Savary et al., 2012; Popp et al., 2013). Hence, improved crop protection is one of the most important strategies to increase agricultural production and food availability. 
Nowadays, management strategies integrate and coordinate a variety of approaches, from cultural practices, the use of resistant or tolerant crop varieties to physical, biological and chemical control methods. Worldwide legislation has now adopted the principles of integrated pest, disease and weed management (IPM), and is promoting methods alternative to pesticides, such as the globally accepted International Code of Conduct on the Distribution and Use of Pesticides (FAO, 2014), the European Union Directive 2009/128/EC or the US Food Quality Protection Act (FQPA). However, local governments still struggle to put the IPM principles into practice, these often being reduced to only chemical control and the implementation of simple warning models for pesticide application.

To ensure global food security, our society requires durable means of managing plant diseases that would be more sustainable, less fungicide-dependent, ecologically safe and socially acceptable. To this end, research on the ecology of phytopathogens needs to provide the basic knowledge to support the development of new control strategies that could be integrated in the IPM practices. A key to understanding the ecology of plant pathogens lies in determining their mode of growth and behavior, which provide microorganisms with survival advantages and increased virulence.

It is becoming increasingly evident that phytopathogens do not interact with the plant as individual entities, but rather at population level, in which microorganisms are social, and engage in complex behavior in response to the surface, other organisms and the extracellular environment. In other words, many plant pathogens form biofilm. The important hallmarks of a biofilm-based infection are increased resistance to conventional biocides, and their capacity for evading the host defenses (Ramage et al., 2012; Balcázar et al., 2015).

The formation of biofilms is not limited to the bacterial world, but rather includes fungal pathogens (Fanning and Mitchell, 2012; Borghi et al., 2015). The interest in fungal pathogenic biofilms relies mainly on the fact that some of the most devastating and universal crop diseases are caused by plant pathogenic fungi. Furthermore, although bacterial biofilms and their role in plant disease have been investigated in detail over a number of years (inter alia Ramey et al., 2004; Danhorn and Fuqua, 2007; Rudrappa et al., 2008; Bogino et al., 2013), much less is known about fungal biofilms. As a consequence, few options are available for controlling fungal pathogens, and chemical fungicides still dominate the market. However, chemical control is only one component of a multifaceted approach that should include more green strategies. Increasing reports of fungicide resistance in plant pathogens, restrictive regulations, and mounting concerns for human and environmental health issues resulting from excessive agrochemical use have stimulated the search for alternative, reliable disease management methods.

The recognition that many plant pathogens - including fungi - grow as biofilms, offers a possibility that they can be controlled adapting new methods and concepts developed by biofilm research.

In this perspective paper, we provide evidence to support the view that the biofilm lifestyle is critical for the pathogenesis of plant diseases, with an emphasis on fungal pathogens. We present an overview of the main factors limiting the durability of modern single-site fungicides, and we assemble the current knowledge on pesticide resistance, addressing this issue in the specific context of the biofilm lifestyle. We also examine the development and exploitation (or potential for exploitation) of a range of innovative, eco-sustainable strategies that take into account the new knowledge about biofilm ecology of pathogens and host-pathogen interactions. Such fungicide-free solutions will be instrumental in reducing disease severity, and will permit a more considerate use of single-site fungicides while decreasing the selection of resistant forms, safeguarding thus the environment.

\section{CURRENT UNDERSTANDING OF FUNGAL BIOFILMS IN PLANT DISEASES}

Current developments in the ecology of plant-pathogen interactions reveal that surface-associated plant pathogens have morphological and physiological features consistent with a biofilm lifestyle. A biofilm is described as a microbial community attached to a surface and embedded in a self-produced matrix of polymeric substances.

Bacterial biofilms causing diseases in plants have been amply reported (inter alia Rojas et al., 2002; Newman et al., 2004; Quiñones et al., 2005; Danhorn and Fuqua, 2007; Chalupowicz et al., 2012). In contrast, plant pathogenic fungi have rarely been described to form biofilm, probably because filamentous fungi cannot fit precisely within the restrictive biofilm definition based on bacterial models. Nevertheless, according to a set of criteria reported by Harding et al. (2009), fungal growth associated with plant disease shows biofilm-like properties, such as extracellular polymeric materials (Figure 1), and populationlevel communication via diffusible extracellular signals. Botrytis cinerea growing on tomato stem was described as heavily layered, with extensive hyphal networks embedded in an exopolymeric matrix (Harding et al., 2010). Phenotypic changes in Fusarium oxysporum f. sp. cucumerinum growing on hard surfaces were reported, revealing a highly heterogeneous architecture composed of robust hyphae and extracellular polysaccharide materials (Peiqian et al., 2014). In this study, the cells in biofilm were less susceptible to heat, cold, UV light and three fungicides than their planktonic form. A number of diffusible extracellular signals, which are typical of a biofilm style, have been detected in fungi and oomycetes. Some of these signals modulate morphology (Hogan, 2006; Madhani, 2011; Barriuso, 2015). Ophiostoma ulmi (syn. Ceratocystis ulmi) produces molecules that repress fungal filamentation (Hornby et al., 2004). Colletotrichum gloeosporioides (syn. Glomerella cingulata) secretes a diffusible factor that suppresses mycelia formation (Lingappa and Lingappa, 1969; Bandara et al., 2012). Ustilago maydis secretes extracellular diffusible pheromones that induce a dimorphic switch from budding to a filamentous and infectious dikaryon form (Jones and Bennett, 2011). In addition, cyclic adenosine monophosphate (cAMP), a universal second messenger that regulates biofilm formation, is sufficient to modulate filamentation in many plant pathogenic fungi, 

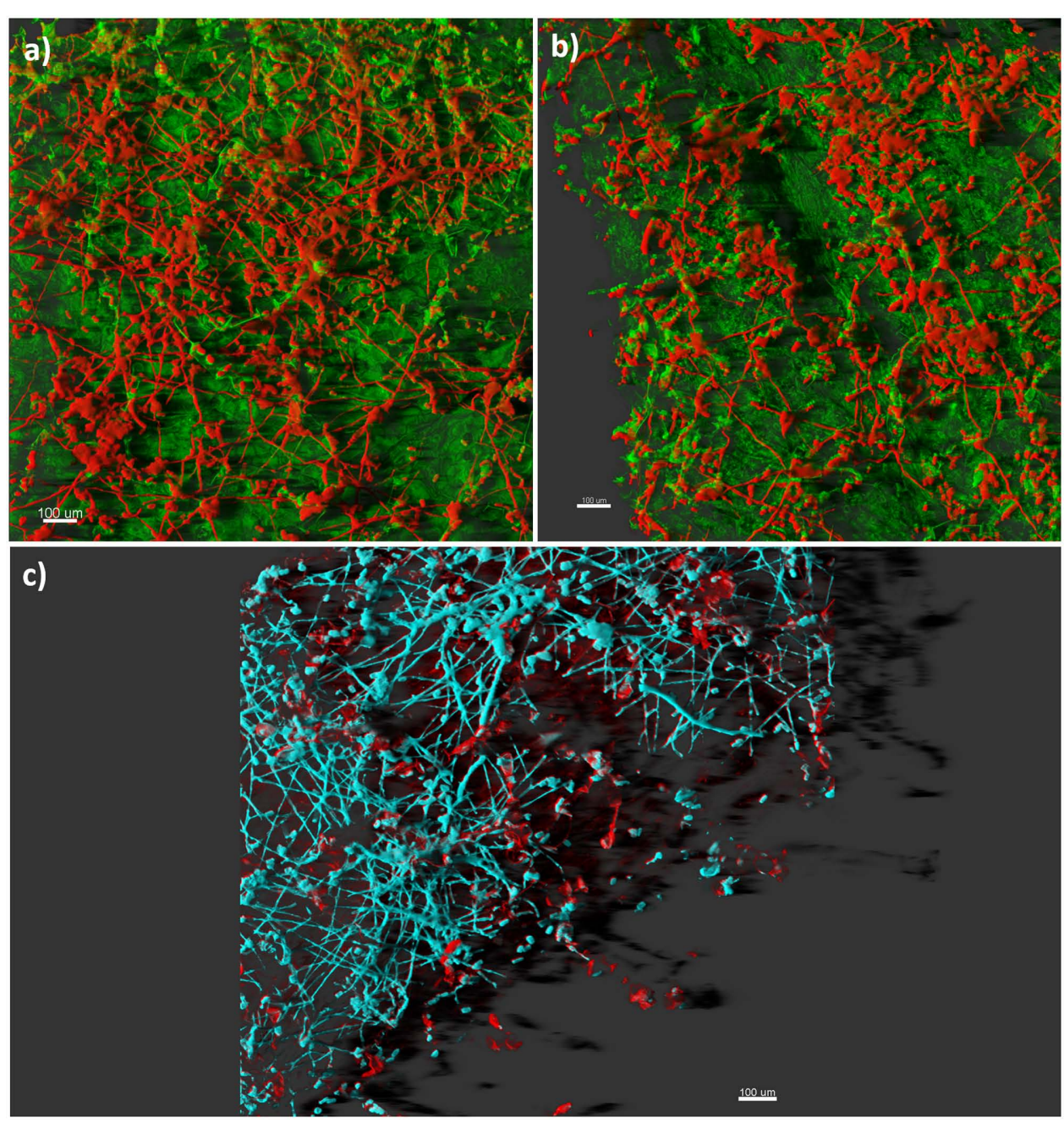

FIGURE 1 | Confocal laser scanning imaging of plant pathogenic fungi. Panels (a) and (b) display a 3D projection of the fungal biofilm that has colonized leaf tissue: extensive hyphal networks and mycelial cords (red), and the plant tissue (green). Panel (c) shows a mature biofilm consisting of hyphal elements (cyano) encased in an extracellular polysaccharide matrix (red). Bars represent $100 \mu \mathrm{m}$.

including the rice blast pathogen Pyricularia oryzae (Ramanujam and Naqvi, 2010; McDonough and Rodriguez, 2011; Franck et al., 2013; Leng and Zhong, 2015; Marroquin-Guzman and Wilson, 2015). Finally, the oomycete Phytophthora nicotianae (syn. P. parasitica) produces a density-dependent signal that modulates the switch from planktonic form to biofilm, leading to massive zoospore encystment and cyst-orientated germination, and the production of extracellular matrix (Galiana et al., 2008; Kong et al., 2010; Theodorakopoulos et al., 2011).

\section{TRADITIONAL BIOFILM CONTROL STRATEGIES: PROBLEMS OF FUNGICIDE-DEPENDENT AGRICULTURE}

The worldwide consumption of pesticides is currently about 1.5 million tons per year, and a total of 353 thousand tons of fungicides and bactericides were consumed per year on average across 77 countries (Liu et al., 2015). In 1999, fungicides in Europe accounted for $61 \%$ of the total pesticide consumption, mostly applied in viticulture and on cereal crops. Since then their use has decreased (Eurostat, 2007); new fungicides are applied at lower rates and over longer time intervals, their efficiency being much higher than that of the first preventative organic compounds. Currently, there is strong public awareness about the safety of chemical products used in plant protection. Indeed, the implementation of new regulations concerning the registration and sustainable use of plant protection products led, in the $\mathrm{EU}$ alone, to the removal of ca. 70\% of the active ingredients used in agriculture before 1993 (European Commission, 2009). As a result, farmers now have to rely on a smaller number of relatively safer products. However, in some cases crop protection management strategies were left with just one - or only a few - active ingredients with different modes of action. This is particularly relevant for minor and specialty crops where only a limited number of fungicides have been registered (Rotteveel 
et al., 2011), and also for rice where, in the EU, the only products available to manage the blast pathogen $P$. oryzae are those containing azoxystrobin and tricyclazole, the latter currently excluded from the list of approved active ingredients and subjected to emergency approval (Kunova et al., 2013, 2014).

Nowadays, it has become increasingly more difficult to develop new fungicides. In 1995 the cost of discovery and the development of a new plant protection product was ca. \$152 million, just 19 years later, in 2014, the cost had increased to $\$ 286$ million, and to meet legislative requirements 3-times as many products had to be screened, increasing the average time of developing a new fungicide from 8.3 to 11.3 years (McDougall, 2016).

The evolution of fungicide resistance among fungal populations is another important factor driving the need to reduce our reliance on conventional fungicides. Most modern fungicides have a single-site mode of action, therefore the evolution of resistance in pathogen populations poses a major problem (Brent and Hollomon, 2007). Indeed, in many cases resistant pathogen populations emerged not long after the fungicides were introduced in practice in the field, and nowadays resistant pathogens are known to almost all the major groups of active ingredients (Table 1; Hayashi et al., 2001; Dubos et al., 2011, 2013; Fungicide Resistance Action Committee [FRAC], 2013, 2014; Lucas et al., 2015; Kunova et al., 2016). The best known is probably the case of strobilurin resistance (Quinone outside inhibitors, QoI; FRAC code 11), where resistant Blumeria graminis $\mathrm{f}$. sp. tritici emerged only 2 years after the introduction of QoI-fungicides (Sierotzki et al., 2000). Moreover, multiple resistance has been observed for some fungal pathogens, in which they exhibit resistance to structurally and functionally unrelated compounds due to the overexpression of efflux pumps of the ATP-binding cassette (ABC) transporters (Leroux et al., 2013; Omrane et al., 2015). Efflux pumps became important in the 1990s as they were involved in the multidrug resistance of tumors, and later also in human pathogens, against clinical fungicides (Sanglard et al., 1995; De Waard et al., 2006; Ramage et al., 2012). To complicate this picture further, some authors have suggested that cross- and multidrug- resistance may be the driving force in the resistance development in fungi that are at the interface among agricultural, domestic, and hospital environments (De Lucca, 2007; Kaur et al., 2012). In fact, threats that fungi pose are not limited to plants; studies have shown that they are emerging as pathogens across diverse organisms, including soft corals (for example, sea-fan aspergillosis caused by Aspergillus sydowii), bees (the microsporidian fungus Nosema sp. associated with colony collapse disorder) and, last but not least, humans and animals (Sharon and Shlezinger, 2013; SolerHurtado et al., 2016). Today, Aspergillus and Fusarium conidia infect millions of susceptible individuals, causing allergies associated with asthma, allergic sinusitis and bronchoalveolitis, frequently with lethal consequences in immunocompromised patients (Źukiewicz-Sobczak, 2013). The plant pathogen Cryptococcus neoformans causes systemic human diseases contracted by inhalation of the infectious particle, which leads to primary pulmonary infections (Srikanta et al., 2014), while the corn smut fungus $U$. maydis causes skin lesions and peritonitis in both humans and animals (McNeil and Palazzi, 2012; Gauthier, 2015).

Moreover, the use of agricultural fungicides may result in the development of resistance in human pathogens, as suggested for A. fumigatus and C. albicans resistant to azoles, where the efflux pumps have been clearly involved in the biofilm resistance (Verweij et al., 2009; Snelders et al., 2012; Lelièvre et al., 2013; Bowyer and Denning, 2014; Faria-Ramos et al., 2014). Genes encoding drug efflux pumps have been reported to be differentially regulated in biofilms during the development and upon the exposure to antimicrobial agents, being predominantly expressed in the early phases and not in mature biofilms (Ramage et al., 2002; Mukherjee et al., 2003; Bueid et al., 2010).

However, efflux pumps are not exclusive determinants of fungal biofilm resistance. Biofilm, due to its cell density and matrix acting as a barrier, may impede the fungicide penetration. Although prevention of penetration is no longer believed to be a significant factor, binding fungicides to components of the biofilm matrix or to fungal membranes may also obstruct their penetration (Apoga et al., 2001; Doss et al., 2003). Positively charged pesticide molecules that bind to negatively charged biofilm matrix polymers might be delayed in their penetration through biofilm. High population densities and proximity of cells in biofilms also increases the chances for genetic exchange among microbial species converting biofilms in hot spots of biocide resistance (Fanning and Mitchell, 2012; Soanes and Richards, 2014; Balcázar et al., 2015).

Another efficient resistance strategy is the production of dormant structures within the biofilm matrix, such as spores, which help fungal plant pathogens to survive unfavorable conditions (Nadal et al., 2008; Gauthier, 2015). The reduced metabolic rate of these dormant structures makes them less sensitive to pesticides compared to active fungi, as widely described for bacterial biofilm (Jabra-Rizk et al., 2004; Van Acker et al., 2014).

These examples demonstrate that plant pathogen resistance, which could also result in treatment failure, could be associated with the ability of fungi to develop biofilm.

\section{NEW ECOLOGICALLY FRIENDLY STRATEGIES TO MANAGE FUNGAL BIOFILMS IN PLANT DISEASES}

In current agricultural production, high yields and healthy crops cannot be achieved without the chemical control of fungal diseases. Because of the many issues concerning fungicides, there is an urgent need for the development of new, efficient and environmentally safe strategies. The goal of these eco-friendly pesticide-free approaches is to prevent plant disease in the first place, not just to replace fungicides; this will help preserve the efficacy of fine fungicides currently on the market, and avoid as much as possible resistance development.

The concept of biofilm in plant pathogenic fungi offers the opportunity to exploit new environmentally friendly agricultural practices. It is reasonable to expect that interfering with the key-steps that orchestrate the genesis of virtually every biofilm 
TABLE 1 | Resistance of fungal plant pathogens to fungicides grouped by their mode of action (MoA).

\begin{tabular}{|c|c|c|c|}
\hline Fungicide MoA & MoA subgroup & $\begin{array}{l}\text { FRAC } \\
\text { Code }\end{array}$ & $\begin{array}{l}\text { No. resistant fungal pathogens } \\
\text { (Fungicide Resistance Action } \\
\text { Committee [FRAC], 2013, 2014) }\end{array}$ \\
\hline \multirow[t]{4}{*}{ A: NUCLEIC ACID SYNTHESIS } & A1: RNA polymerase I: PA Fungicides (PhenylAmides) & 4 & 36 (oomycetes) \\
\hline & A2: Adenosine deaminase & 8 & 2 (powdery mildews) \\
\hline & A3: DNA/RNA synthesis (proposed) & 32 & RESISTANCE NOT KNOWN \\
\hline & A4: DNA topoisomerase type II (gyrase): Carboxylic acids (Bactiricide) & 31 & 1 (Erwinia amylovora) \\
\hline \multirow[t]{5}{*}{$\begin{array}{l}\text { B: MITOSIS AND CELL } \\
\text { DIVISION }\end{array}$} & $\begin{array}{l}\text { B1: } \beta \text {-tubulin assembly in mitosis: MBC Methyl Benzimidazole } \\
\text { Carbamates }\end{array}$ & 1 & 114 \\
\hline & B2: $\beta$-tubulin assembly in mitosis: $\mathrm{N}$-phenylcarbamates & 10 & 4 \\
\hline & B3: $\beta$-tubulin assembly in mitosis: Benzamides & 22 & RESISTANCE NOT KNOWN \\
\hline & B4: Cell division (proposed) & 20 & 1 (Rhizoctonia solani) - laboratory \\
\hline & B5: Delocalisation of spectrin like proteins & 43 & RESISTANCE NOT KNOWN \\
\hline \multirow[t]{8}{*}{ C: RESPIRATION } & C1: Complex I, NADH oxidoreductase & 39 & RESISTANCE NOT KNOWN \\
\hline & C2: Complex II, succinate-dehydrogenase: SDHI fungicides & 7 & 11 \\
\hline & C3: Complex III, cytochrome bc1: Quinone Outside Inhibitors & 11 & 52 \\
\hline & C4: Complex III, cytochrome bc1: Quinone Inside Inhibitors & 21 & 1 (Phytophthora capsici) - field \\
\hline & C5: Uncouplers of oxidative phosphorylation & 29 & 1 (Botrytis cinerea) - field \\
\hline & C6: Inhibitors of oxidative phosphorylation. ATP synthase & 30 & 1 (Cercospora beticola) \\
\hline & C7: ATP production (proposed) & 38 & 1 (Gaeumannomyces graminis) -field \\
\hline & C8: Complex III, cytochrome bc1: Qx (unknown) site & 45 & NA \\
\hline \multirow{5}{*}{$\begin{array}{l}\text { D: AMINO ACIDS AND } \\
\text { PROTEIN SYNTHESIS }\end{array}$} & D1: Methionine biosynthesis (proposed; cgs gene): Anilinopyrimidines & 9 & 3 \\
\hline & D2: Protein synthesis: Enopyranuronic acid antibiotic & 23 & 2 - laboratory \\
\hline & D3: Protein synthesis: Hexapyranosyl antibiotic & 24 & 2 \\
\hline & D4: Protein synthesis: Glucopyranosyl antibiotic (Bactericide) & 25 & 8 \\
\hline & D5: Protein synthesis: Tetracycline antibiotic (Bactericide) & 41 & 3 \\
\hline \multirow[t]{3}{*}{ E: SIGNAL TRANSDUCTION } & E1: Signal transduction: Aza-naphthalenes & 13 & 3 (powdery mildews) \\
\hline & $\begin{array}{l}\text { E2: MAP/Histidine-kinase in osmotic signal transduction (os-2, HOG1): } \\
\text { Phenylpyrroles }\end{array}$ & 12 & 6 - mostly laboratory \\
\hline & $\begin{array}{l}\text { E3: MAP/Histidine-kinase in osmotic signal transduction (os-1, Daf1): } \\
\text { Dicarboximides }\end{array}$ & 2 & 19 \\
\hline \multirow{5}{*}{$\begin{array}{l}\text { F: LIPIDS AND MEMBRANE } \\
\text { SYNTHESIS }\end{array}$} & F2: Phospholipid biosynthesis, methyl transferase & 6 & 2 \\
\hline & F3: Lipid peroxidation (proposed): Aromatic Hydrocarbons & 14 & 4 \\
\hline & F4: Cell membrane permeability, fatty acids (proposed): Carbamates & 28 & 8 (Pythium spp.) \\
\hline & $\begin{array}{l}\text { F6: Microbial disrupters of pathogen cell membranes: Bacillus } \\
\text { subtilis and the fungicidal lipopeptides produced }\end{array}$ & 44 & RESISTANCE NOT KNOWN \\
\hline & F7: Membrane disruption (proposed): Plant extract & 46 & RESISTANCE NOT KNOWN \\
\hline \multirow[t]{4}{*}{$\begin{array}{l}\text { G: STEROL BIOSYNTHESIS IN } \\
\text { MEMBRANES }\end{array}$} & $\begin{array}{l}\text { G1: C14 demethylase in sterol biosynthesis (erg11/cyp51): DMl } \\
\text { fungicides }\end{array}$ & 3 & 35 \\
\hline & $\begin{array}{l}\text { G2: } \Delta 14 \text { reductase and } \Delta 8-\Delta 7 \text { isomerase in sterol-biosynthesis } \\
\text { (erg24, erg2): Amines ('morpholines') }\end{array}$ & 5 & 4 \\
\hline & G3: 3-keto reductase, C4-demethylation (erg27): Hydroxyanilides & 17 & 1 (Botrytis cinerea) - field \\
\hline & $\begin{array}{l}\text { G4: Squalene epoxidase in sterol biosynthesis (erg1): SBI class } \\
\text { IV }\end{array}$ & 18 & RESISTANCE NOT KNOWN \\
\hline \multirow[t]{3}{*}{ H: CELL WALL BIOSYNTHESIS } & $\begin{array}{l}\text { H3: Trehalase and inositol biosynthesis: Glucopyranosyl } \\
\text { antibiotic }\end{array}$ & 26 & RESISTANCE NOT KNOWN \\
\hline & H4: Chitin synthase: Polyoxins & 19 & 6 \\
\hline & H5: Cellulose synthase: CAA fungicides. Carboxylic Acid Amides & 40 & 6 (oomycetes) \\
\hline \multirow[t]{2}{*}{$\begin{array}{l}\text { I: MELANIN SYNTHESIS IN } \\
\text { CELL WALL }\end{array}$} & $\begin{array}{l}\text { 11: Reductase in melanin biosynthesis: MBI-R Melanin Biosynthesis } \\
\text { Inhibitors - Reductase }\end{array}$ & 16.1 & 1 (Pyricularia oryzae) - laboratory \\
\hline & $\begin{array}{l}\text { I2: Dehydratase in melanin biosynthesis: MBI-D Melanin Biosynthesis } \\
\text { Inhibitors - Dehydratase }\end{array}$ & 16.2 & 1 (Pyricularia oryzae) - field \\
\hline
\end{tabular}


TABLE 1 | Continued

\begin{tabular}{|c|c|c|c|}
\hline Fungicide MoA & MoA subgroup & $\begin{array}{l}\text { FRAC } \\
\text { Code }\end{array}$ & $\begin{array}{l}\text { No. resistant fungal pathogens } \\
\text { (Fungicide Resistance Action } \\
\text { Committee [FRAC], 2013, 2014) }\end{array}$ \\
\hline \multirow{5}{*}{$\begin{array}{l}\text { P: HOST PLANT DEFENSE } \\
\text { INDUCTION }\end{array}$} & P1: Salicylic acid pathway: Benzothiadiazole BTH & P1 & RESISTANCE NOT KNOWN \\
\hline & P2: Benzisothiazole & P2 & RESISTANCE NOT KNOWN \\
\hline & P3: Thiadiazole-carboxamide & P3 & RESISTANCE NOT KNOWN \\
\hline & P4: Natural compound & P4 & RESISTANCE NOT KNOWN \\
\hline & P5: Plant extract & P5 & RESISTANCE NOT KNOWN \\
\hline \multirow{14}{*}{$\begin{array}{l}\text { U: UNKNOWN MODE OF } \\
\text { ACTION }\end{array}$} & Unknown: Cyanoacetamide-oxime & 27 & 1 (Plasmopara viticola) - field \\
\hline & Unknown: Phosphonates & 33 & 4 \\
\hline & Unknown: Phthalamic acids & 34 & RESISTANCE NOT KNOWN \\
\hline & Unknown: Benzotriazines & 35 & RESISTANCE NOT KNOWN \\
\hline & Unknown: Benzene-sulfonamides & 36 & RESISTANCE NOT KNOWN \\
\hline & Unknown: Pyridazinones & 37 & RESISTANCE NOT KNOWN \\
\hline & Unknown: Thiocarbamate & 42 & RESISTANCE NOT KNOWN \\
\hline & Unknown: Phenyl-acetamide & U6 & 1 (Podosphaera fusca) - glasshouse \\
\hline & Actin disruption (proposed): Benzophenone & U8 & 1 (Blumeria graminis f.sp. tritici) - field \\
\hline & Cell membrane disruption (proposed): Guanidines (dodine) & U12 & 1 (Venturia inaequalis) \\
\hline & Unknown: Thiazolidine & U13 & RESISTANCE NOT KNOWN \\
\hline & Unknown: Pyrimidinone-hydrazones & U14 & RESISTANCE NOT KNOWN \\
\hline & Oxysterol binding protein (OSBP) inhibition (proposed) & U15 & RESISTANCE NOT KNOWN \\
\hline & Complex III: cytochrome bc1, unknown binding site (proposed) & U16 & RESISTANCE NOT KNOWN \\
\hline \multirow[t]{11}{*}{$\begin{array}{l}\text { M: MULTI-SITE CONTACT } \\
\text { ACTIVITY }\end{array}$} & Multi-site contact activity: Inorganic (copper) & M1 & $\begin{array}{l}1 \text { (Xanthomonas axonopodis pv. citri) - } \\
\text { field }\end{array}$ \\
\hline & Multi-site contact activity: Inorganic (sulfur) & M2 & RESISTANCE NOT KNOWN \\
\hline & Multi-site contact activity: Dithiocarbamates and relatives & M3 & 2 - laboratory \\
\hline & Multi-site contact activity: Phthalimides & M4 & $\begin{array}{l}1 \text { (Botrytis cinerea) - laboratory, } \\
\text { glasshouse }\end{array}$ \\
\hline & Multi-site contact activity: Chloronitriles (phthalonitriles) & M5 & 1 (Botrytis cinerea) - laboratory \\
\hline & Multi-site contact activity: Sulfamides & M6 & 1 (Botrytis cinerea) - laboratory \\
\hline & Multi-site contact activity: Guanidines & M7 & 4 \\
\hline & Multi-site contact activity: Triazines & M8 & RESISTANCE NOT KNOWN \\
\hline & Multi-site contact activity: Quinones & M9 & RESISTANCE NOT KNOWN \\
\hline & Multi-site contact activity: Quinoxalines & M10 & RESISTANCE NOT KNOWN \\
\hline & Multi-site contact activity: Maleimide & M11 & RESISTANCE NOT KNOWN \\
\hline
\end{tabular}

(e.g., attachment, cell-to-cell communication, dispersion) could provide a way for new preventive strategies that do not necessarily exert lethal effects on cells, but rather sabotage the propensity for a biofilm lifestyle (Villa et al., 2013b). As these substances do not act by killing the cells, they should not impose a selective pressure that would cause the onset of resistance (Villa and Cappitelli, 2013).

Sub-lethal concentrations of zosteric acid (ZA), a secondary metabolite from the seagrass Zostera marina, reduce fungal adhesion and play a pivotal role in affecting fungal biofilm thickness and morphology (Stanley et al., 2002; Villa et al., 2010, 2011). The cells remain metabolically active but are unable to form filamentous structures. Moreover, ZA extends the performance of antimicrobial agents, shows cytocompatibility with soft and hard tissues, low bioaccumulation potential and absence of toxicity on Daphnia magna (Villa et al., 2011; Polo et al., 2014). ZA affects oxidative balance by interacting with the
NADH: quinone reductase (WrbA), an enzyme belonging to a family of flavoprotein quinone reductases widely distributed in fungi (Villa et al., 2012; Cattò et al., 2015). The involvement of $\mathrm{ZA}$ in oxidative stress response is particularly promising as an alternative to conventional control strategies, as shown by the importance of ROS in fungal development and pathogenicity of several phytopathogenic fungi (Heller and Tudzynski, 2011; Mir et al., 2015).

Caripyrin, a pyridyloxirane recently isolated from submerged cultures of the basidiomycete Gymnopus montagnei (syn. Caripia montagnei), was found to inhibit conidial germination and appressorium formation in $P$. oryzae without being cytotoxic, antibacterial and nematicidal (Rieger et al., 2010). Candida biofilm formation was reduced by $63-98 \%$ when sub-MIC levels of Boesenbergia pandurata (finger root) oil were used (Taweechaisupapong et al., 2010). Purpurin, a natural red anthraquinone pigment commonly found in madder root, 
blocked C. albicans yeast-to-hypha transition when used at a sub-lethal concentration by down-regulating the expression of hypha-specific genes and the hyphal regulator RAS1 (Tsang et al., 2012). Pomegranate extract and its major component ellagic acid have anti-biofilm activity against $C$. albicans at sub-inhibitory concentrations (Bakkiyaraj et al., 2013). It also disrupted pre-formed biofilms and inhibited germ tube formation. Sub-lethal concentration of the bulb extract of Muscari comosum reduced the adhesion of $C$. albicans and induced the dispersion of biofilm cells in a dose-dependent manner (Villa et al., 2013a).

Although most of these studies have been conducted on the fungal model C. albicans, it is reasonable to expect that also fungal phytopathogens using dimorphism as a virulence strategy, such as U. maydis, Mycosphaerella graminicola, Taphrina deformans, or O. ulmi (Nadal et al., 2008), may be affected by these compounds, highlighting the potential effectiveness of biocide-free approaches.

The potential of antibiofilm compounds at sub-lethal concentrations has been proved against phytopathogenic bacteria, demonstrating - to some extent - the feasibility of the proposed antifungal strategy. A recent study showed that salicylic acid attenuates biofilm formation, swimming motility and acyl homoserine lactone production by different plant pathogens such as Erwinia amylovora, Pseudomonas corrugata, P. syringae pv syringae, Xanthomonas campestris pv campestris, and Pectobacterium carotovorum (Lagonenko et al., 2013). D-leucine and 3-indoloacetonitrile, which have been shown to inhibit biofilm formation and virulence in human bacterial pathogens, effectively prevented biofilm formation by the causal agent of citrus canker $X$. citri subsp. citri. The compounds were effective on different abiotic surfaces as well as on citrus leaves at sub-inhibitory concentrations, by repressing the expression of chemotaxis/motility-related genes in the phytopathogen ( $\mathrm{Li}$ and Wang, 2014).

Understanding the consequences of biofilm manipulation could provide new antifungal targets as well as an important insight into the role of the biofilm mode of life in regulating stress or fungicide resistance.

\section{REFERENCES}

Alexandratos, N., and Bruinsma, J. (2012). World Agriculture: Towards 2015/2030: the 2012 Revision. ESA Working paper No 12-03. Rome: FAO. doi: 10.1016/ S0264-8377(03)00047-4

Apoga, D., Ek, B., and Tunlid, A. (2001). Analysis of proteins in the extracellular matrix of the plant pathogenic fungus Bipolaris sorokiniana using 2-D gel electrophoresis and MS / MS. FEMS Microbiol. Lett. 197, 1-6.

Bakkiyaraj, D., Nandhini, J. R., Malathy, B., and Pandian, S. K. (2013). The antibiofilm potential of pomegranate (Punica granatum L.) extract against human bacterial and fungal pathogens. Biofouling 29, 929-937. doi: 10.1080/08927014. 2013.820825

Balcázar, J. L., Subirats, J., and Borrego, C. M. (2015). The role of biofilms as environmental reservoirs of antibiotic resistance. Front. Microbiol. 6:1216. doi: $10.3389 /$ fmicb. 2015.01216

Bandara, H. M. H. N., Lam, O. L. T., Jin, L. J., and Samaranayake, L. (2012). Microbial chemical signaling: a current perspective. Crit. Rev. Microbiol. 38, 217-249. doi: 10.3109/1040841X.2011.652065

\section{CONCLUSION}

Fungal pathogens of cultivated crops remain a threat to food security also in the $21^{\text {st }}$ century, and the incorporation of new alternatives to conventional fungicides in disease management provides a sustainable approach for disease prevention and management. This is especially true in the light of the major challenges of efficiently increasing and protecting crop yield, while maintaining economic profits and at the same time preserving human health and the environment.

Some examples presented in this perspective paper provide possible solutions to reduce reliance on conventional fungicides for crop protection. Antibiofilm compounds at sub-lethal concentrations have partially been explored in the past and in other scientific fields. However, the challenge now is to take this knowledge and apply it in the agricultural context to develop novel tools for managing disease and to understand which of these strategies have the best potential in various environmental scenarios. This constitutes a long-term challenge that requires interdisciplinary research to address major issues of relevance to both science and society.

\section{AUTHOR CONTRIBUTIONS}

FV and AK wrote the manuscript. FV performed the confocal microscopy. FC and PC participated in discussions and improved the manuscript. AK coordinated the collaboration of the authors. All authors read and approved the final manuscript.

\section{ACKNOWLEDGMENTS}

This work was partially supported by the German DAAD and the Italian CRUI in the framework of the Vigoni project 2016 "Bioactive secondary compounds from halophyte species inhibit biofilm formation of plant-pathogenic microorganisms on plant surfaces."

Barriuso, J. (2015). Quorum sensing mechanisms in fungi. AIMS Microbiol. 1, 37-47. doi: 10.3934/microbiol.2015.1.37

Bogino, P. C., Oliva, Mde L, Sorroche, F. G., and Giordano, W. (2013). The role of bacterial biofilms and surface components in plant-bacterial associations. Int. J. Mol. Sci. 14, 15838-15859. doi: 10.3390/ijms140815838

Borghi, E., Morace, G., Borgo, F., Rajendran, R., Sherry, L., Nile, C., et al. (2015). New strategic insights into managing fungal biofilms. Front. Microbiol. 6:1077. doi: $10.3389 /$ fmicb.2015.01077

Bowyer, P., and Denning, D. W. (2014). Environmental fungicides and triazole resistance in Aspergillus. Pest Manag. Sci. 70, 173-178. doi: 10.1002/ps.3567

Brent, K. J., and Hollomon, D. W. (2007). Fungicide Resistance in Crop Pathogens: How Can it be Managed?. Brussels: Fungicide Resistance Action Committee (Croplife International).

Bueid, A., Howard, S. J., Moore, C. B., Richardson, M. D., Harrison, E., Bowyer, P., et al. (2010). Azole antifungal resistance in Aspergillus fumigatus: 2008 and 2009. J. Antimicrob. Chemother. 65, 2116-2118. doi: 10.1093/jac/dkq279

Cattò, C., Dell'Orto, S., Villa, F., Villa, S., Gelain, A., Vitali, A., et al. (2015). Unravelling the structural and molecular basis responsible for the anti-biofilm 
activity of zosteric acid. PLoS ONE 10:e0131519. doi: 10.1371/journal.pone. 0131519

Chalupowicz, L., Zellermann, E.-M., Fluegel, M., Dror, O., Eichenlaub, R., Gartemann, K.-H., et al. (2012). Colonization and movement of GFP-labeled Clavibacter michiganensis subsp. michiganensis during tomato infection. Phytopathology 102, 23-31. doi: 10.1094/PHYTO-05-11-0135

Danhorn, T., and Fuqua, C. (2007). Biofilm formation by plant-associated bacteria. Annu. Rev. Microbiol. 61, 401-422. doi: 10.1146/annurev.micro.61.080706. 093316

De Lucca, A. J. (2007). Harmful fungi in both agriculture and medicine. Rev. Iberoam. Micol. 24, 3-13.

De Waard, M. A., Andrade, A. C., Hayashi, K., Schoonbeek, H. J., Stergiopoulos, I., and Zwiers, L. H. (2006). Impact of fungal drug transporters on fungicide sensitivity, multidrug resistance and virulence. Pest Manag. Sci. 62, 195-207. doi: $10.1002 /$ ps. 1150

Doss, R. P., Deisenhofer, J., Von Nidda, H. A. K., Soeldner, A. H., and McGuire, R. P. (2003). Melanin in the extracellular matrix of germlings of Botrytis cinerea. Phytochemistry 63, 687-691. doi: 10.1016/S0031-9422(03)00323-6

Dubos, T., Pasquali, M., Pogoda, F., Casanova, A., Hoffmann, L., and Beyer, M. (2013). Differences between the succinate dehydrogenase sequences of isopyrazam sensitive Zymoseptoria tritici and insensitive Fusarium graminearum strains. Pestic. Biochem. Physiol. 105, 28-35. doi: 10.1016/j.pestbp. 2012.11.004

Dubos, T., Pasquali, M., Pogoda, F., Hoffmann, L., and Beyer, M. (2011). Evidence for natural resistance towards trifloxystrobin in Fusarium graminearum. Eur. J. Plant Pathol. 130, 239-248. doi: 10.1007/s10658-011-9749-7

European Commission (2009). EU Action on Pesticides: "Our Food has Become Greener." Available at: http://ec.europa.eu/food/plant/plant_protection_ products/eu_policy/docs/factsheet_pesticides_en.pdf [accessed February 10, 2014].

Eurostat (2007). The Use of Plant Protection Products in the European Union. Data 1992-2003, ed. P. Nadin (Luxembourg: European Commission).

Fanning, S., and Mitchell, A. P. (2012). Fungal biofilms. PLoS Pathog. 8:e1002585. doi: 10.1371/journal.ppat. 1002585

FAO (2014). International Code of Conduct on Pesticide Management. Rome: World Health Organization AND Food and Agriculture Organization of the United Nations.

Faria-Ramos, I., Tavares, P. R., Farinha, S., Neves-Maia, J., Miranda, I. M., Silva, R. M., et al. (2014). Environmental azole fungicide, prochloraz, can induce cross-resistance to medical triazoles in Candida glabrata. FEMS Yeast Res. 14, 1119-1123. doi: 10.1111/1567-1364.12193

Franck, W. L., Gokce, E., Oh, Y. Y., Muddiman, D. C., and Dean, R. A. (2013). Temporal analysis of the Magnaporthe oryzae proteome during conidial germination and cyclic AMP (cAMP)-mediated appressorium formation. Mol. Cell. Proteomics 12, 2249-2265. doi: 10.1074/mcp.M112.025874

Fungicide Resistance Action Committee [FRAC] (2013). FRAC List of Plant Pathogenic Organisms Resistant to Disease Control Agents. Available at: www. frac.info

Fungicide Resistance Action Committee [FRAC] (2014). FRAC Code List 2014: Fungicides Sorted by Mode of Action (Including FRAC Code Numbering). Available at: www.frac.info

Galiana, E., Fourré, S., and Engler, G. (2008). Phytophthora parasitica biofilm formation: installation and organization of microcolonies on the surface of a host plant. Environ. Microbiol. 10, 2164-2171. doi: 10.1111/j.1462-2920.2008. 01619.x

Gauthier, G. M. (2015). Dimorphism in fungal pathogens of mammals, plants, and insects. PLoS Pathog. 11:e1004608. doi: 10.1371/journal.ppat.1004608

Harding, M. W., Marques, L. L. R., Howard, R. J., and Olson, M. E. (2009). Can filamentous fungi form biofilms? Trends Microbiol. 17, 475-480. doi: 10.1016/j. tim.2009.08.007

Harding, M. W., Marques, L. L. R., Howard, R. J., and Olson, M. E. (2010). Biofilm morphologies of plant pathogenic fungi. Am. J. Plant Sci. Biotechnol. 4, 43-47.

Hayashi, K., Schoonbeek, H., Sugiura, H., and De Waard, M. A. (2001). Multidrug resistance in Botrytis cinerea associated with decreased accumulation of the azole fungicide oxpoconazole and increased transcription of the $\mathrm{ABC}$ transporter gene BcatrD. Pestic. Biochem. Physiol. 70, 168-179. doi: 10.1006/ pest.2001.2548
Heller, J., and Tudzynski, P. (2011). Reactive oxygen species in phytopathogenic fungi: signaling, development, and disease. Annu. Rev. Phytopathol. 49, 369390. doi: 10.1146/annurev-phyto-072910-095355

Hogan, D. A. (2006). Talking to themselves : autoregulation and quorum sensing in fungi. Eukaryot. Cell 5, 613-619. doi: 10.1128/EC.5.4.613

Hornby, J. M., Jacobitz-kizzier, S. M., Mcneel, D. J., Jensen, E. C., Treves, D. S., Nickerson, K., et al. (2004). Inoculum size effect in dimorphic fungi?: extracellular control of yeast-mycelium dimorphism in Ceratocystis ulmi. Appl. Environ. Microbiol. 70, 1356-1359. doi: 10.1128/AEM.70.3.1356

Jabra-Rizk, M. A., Falkler, W. A., and Meiller, T. F. (2004). Fungal biofilms and drug resistance. Emerg. Infect. Dis. 10, 14-19. doi: 10.3201/eid1001.030119

Jones, S. K., and Bennett, R. J. (2011). Fungal mating pheromones: choreographing the dating game. Fungal Genet. Biol. 48, 668-676. doi: 10.1016/j.fgb.2011.04.001

Kaur, S., Dhillon, G. S., Brar, S. K., Vallad, G. E., Chand, R., and Chauhan, V. B. (2012). Emerging phytopathogen Macrophomina phaseolina : biology, economic importance and current diagnostic trends. Crit. Rev. Microbiol. 38, 136-151. doi: 10.3109/1040841X.2011.640977

Kong, P., Tyler, B. M., Richardson, P. A., Lee, B. W. K., Zhou, Z. S., and Hong, C. (2010). Zoospore interspecific signaling promotes plant infection by Phytophthora. BMC Microbiol. 10:313. doi: 10.1186/1471-2180-10-313

Kunova, A., Pizzatti, C., Bonaldi, M., and Cortesi, P. (2014). Sensitivity of nonexposed and exposed populations of Magnaporthe oryzae from rice to tricyclazole and azoxystrobin. Plant Dis. 98, 512-518. doi: 10.1094/PDIS-0413-0432-RE

Kunova, A., Pizzatti, C., Bonaldi, M., and Cortesi, P. (2016). Metrafenone resistance in a population of Erysiphe necator in northern Italy. Pest Manag. Sci. 2, 398-404. doi: 10.1002/ps.4060

Kunova, A., Pizzatti, C., and Cortesi, P. (2013). Impact of tricyclazole and azoxystrobin on growth, sporulation and secondary infection of the rice blast fungus, Magnaporthe oryzae. Pest Manag. Sci. 69, 278-284. doi: 10.1002/ps. 3386

Lagonenko, L., Lagonenko, A., and Evtushenkov, A. (2013). Impact of salicylic acid on biofilm formation by plant pathogenic bacteria. J. Biol. Earth Sci. 3, 176-181.

Lelièvre, L., Groh, M., Angebault, C., Maherault, A. C., Didier, E., and Bougnoux, M. E. (2013). Azole resistant Aspergillus fumigatus: an emerging problem. Med. Mal. Infect. 43, 139-145. doi: 10.1016/j.medmal.2013.02.010

Leng, Y., and Zhong, S. (2015). The role of mitogen-activated protein (MAP) kinase signaling components in the fungal development, stress response and virulence of the fungal cereal pathogen Bipolaris sorokiniana. PLoS ONE 10:e0128291. doi: 10.1371/journal.pone.0128291

Leroux, P., Gredt, M., Remuson, F., Micoud, A., and Walker, A.-S. (2013). Fungicide resistance status in French populations of the wheat eyespot fungi Oculimacula acuformis and Oculimacula yallundae. Pest Manag. Sci. 69, 15-26. doi: $10.1002 /$ ps.3408

Li, J., and Wang, N. (2014). Foliar application of biofilm formation-inhibiting compounds enhances control of citrus canker caused by Xanthomonas citri subsp. citri. Phytopathol 2, 134-142. doi: 10.1094/PHYTO-04-13-0100-R

Lingappa, B. T., and Lingappa, Y. (1969). Role of auto-inhibitors on mycelial growth and dimorphism of Glomerella cingulata. J. Gen. Microbiol. 56, 35-45. doi: 10.1099/00221287-56-1-35

Liu, Y., Pan, X., and Li, J. (2015). A 1961-2010 record of fertilizer use, pesticide application and cereal yields: a review. Agron. Sustain. Dev. 35, 83-93. doi: 10.1007/s13593-014-0259-9

Lucas, J. A., Hawkins, N. J., and Fraaije, B. A. (2015). The evolution of fungicide resistance. Adv. Appl. Microbiol. 90, 30-92. doi: 10.1016/bs.aambs.2014.09.001

Madhani, H. D. (2011). Quorum sensing in fungi: Q\&A. PLoS Pathog. 7:e1002301. doi: 10.1371/journal.ppat.1002301

Marroquin-Guzman, M., and Wilson, R. A. (2015). GATA-dependent glutaminolysis drives appressorium formation in Magnaporthe oryzae by suppressing TOR inhibition of cAMP/PKA signaling. PLoS Pathog. 11:e1004851. doi: 10.1371/journal.ppat.1004851

McDonough, K. A., and Rodriguez, A. (2011). The myriad roles of cyclic AMP in microbial pathogens: from signal to sword. Nat. Rev. Microbiol. 10, 27-38. doi: $10.1038 /$ nrmicro2688

McDougall, P. (2016). The Cost of New Agrochemical Product Discovery, Development and Registration in 1995, 2000, 2005-8 and 2010 to 2014. $R$ \& $D$ expenditure in 2014 and Expectations for 2019. Midlothian: Phillips McDougall. 
McNeil, J. C., and Palazzi, D. L. (2012). Ustilago as a cause of fungal peritonitis: case report and review of the literature. J. Ped. Infect. Dis. Soc. 1, 337-339. doi: 10.1093/jpids/pis043

Mir, A. A., Park, S.-Y., Sadat, M. A., Kim, S., Choi, J., Jeon, J., et al. (2015), Systematic characterization of the peroxidase gene family provides new insights into fungal pathogenicity in Magnaporthe oryzae. Sci. Rep. 5:11831. doi: $10.1038 /$ srep 11831

Mukherjee, P. K., Chandra, J., Kuhn, D. M., and Ghannoum, M. A. (2003). Mechanism of fluconazole resistance in Candida albicans biofilms: phasespecific role of efflux pumps and membrane sterols. Infect. Immun. 71, 4333-4340. doi: 10.1128/IAI.71.8.4333-4340.2003

Nadal, M., García-Pedrajas, M. D., and Gold, S. E. (2008). Dimorphism in fungal plant pathogens. FEMS Microbiol. Lett. 284, 127-134. doi: 10.1111/j.1574-6968. 2008.01173.x

Newman, K. L., Almeida, R. P., Purcell, A. H., and Lindow, S. E. (2004). Cell-cell signaling controls Xylella fastidiosa interactions with both insects and plants. Proc. Natl. Acad. Sci. U.S.A. 101, 1737-1742. doi: 10.1073/pnas.0308399100

Oerke, E. C., and Dehne, H. W. (2004). Safeguarding production - Losses in major crops and the role of crop protection. Crop Prot. 23, 275-285. doi: 10.1016/j. cropro.2003.10.001

Omrane, S., Sghyer, H., Audéon, C., Lanen, C., Duplaix, C., Walker, A.-S., et al. (2015). Fungicide efflux and the MgMFS1 transporter contribute to the multidrug resistance phenotype in Zymoseptoria tritici field isolates. Environ. Microbiol. 17, 2805-2823. doi: 10.1111/1462-2920.12781

Peiqian, L., Xiaoming, P., Huifang, S., Jingxin, Z., Ning, H., and Birun, L. (2014). Biofilm formation by Fusarium oxysporum f. sp. cucumerinum and susceptibility to environmental stress. FEMS Microbiol. Lett. 350, 138-145. doi: 10.1111/1574-6968.12310

Polo, A., Foladori, P., Ponti, B., Bettinetti, R., Gambino, M., Villa, F., et al. (2014). Evaluation of zosteric acid for mitigating biofilm formation of Pseudomonas putida isolated from a membrane bioreactor system. Int. J. Mol. Sci. 15, 9497-9518. doi: 10.3390/ijms15069497

Popp, J., Peto, K., and Nagy, J. (2013). Pesticide productivity and food security. A review. Agron. Sustain. Dev. 33, 243-255. doi: 10.1007/s13593-012-0105-x

Quiñones, B., Dulla, G., and Lindow, S. E. (2005). Quorum sensing regulates exopolysaccharide production, motility, and virulence in Pseudomonas syringae. Mol. Plant Microbe Interact. 18, 682-693. doi: 10.1094/MPMI-180682

Ramage, G., Bachmann, S., Patterson, T. F., Wickes, B. L., and López-Ribot, J. L. (2002). Investigation of multidrug efflux pumps in relation to fluconazole resistance in Candida albicans biofilms. J. Antimicrob. Chemother. 49, 973-980. doi: $10.1093 / \mathrm{jac} / \mathrm{dkf049}$

Ramage, G., Rajendran, R., Sherry, L., and Williams, C. (2012). Fungal biofilm resistance. Int. J. Microbiol. 2012, 14. doi: 10.1155/2012/528521

Ramanujam, R., and Naqvi, N. I. (2010). PdeH, a high-affinity camp phosphodiesterase, is a key regulator of asexual and pathogenic differentiation in Magnaporthe oryzae. PLoS Pathog. 6:e1000897. doi: 10.1371/journal.ppat. 1000897

Ramey, B. E., Koutsoudis, M., von Bodman, S. B., and Fuqua, C. (2004). Biofilm formation in plant-microbe associations. Curr. Opin. Microbiol. 7, 602-609. doi: 10.1016/j.mib.2004.10.014

Rieger, P. H., Liermann, J. C., Opatz, T., Anke, H., and Thines, E. (2010). Caripyrin, a new inhibitor of infection-related morphogenesis in the rice blast fungus Magnaporthe oryzae. J. Antibiot. (Tokyo). 63, 285-289. doi: 10.1038/ja. 2010.31

Rojas, C. M., Ham, J. H., Deng, W.-L., Doyle, J. J., and Collmer, A. (2002). HecA, a member of a class of adhesins produced by diverse pathogenic bacteria, contributes to the attachment, aggregation, epidermal cell killing, and virulence phenotypes of Erwinia chrysanthemi EC16 on Nicotiana clevelandii seedlings. Proc. Natl. Acad. Sci. U.S.A. 99, 13142-13147. doi: 10.1073/pnas.20235 8699

Rotteveel, T., Jorgensen, L. N., and Heimbach, U. (2011). Resistance management in Europe: a preliminary proposal for the determination of a minimum number of active substances necessary to manage resistance. EPPO Bull. 41, 432-438. doi: 10.1111/j.1365-2338.2011.02516.x

Rudrappa, T., Biedrzycki, M. L., and Bais, H. P. (2008). Causes and consequences of plant-associated biofilms. FEMS Microbiol. Ecol. 64, 153-166. doi: 10.1111/j. 1574-6941.2008.00465.x
Sanglard, D., Kuchler, K., Ischer, F., Pagani, J. L., Monod, M., and Bille, J. (1995). Mechanisms of resistance to azole antifungal agents in Candida albicans isolates from AIDS patients involve specific multidrug transporters. Antimicrob. Agents Chemother. 39, 2378-2386. doi: 10.1128/AAC.39.11. 2378

Savary, S., Ficke, A., Aubertot, J. N., and Hollier, C. (2012). Crop losses due to diseases and their implications for global food production losses and food security. Food Secur. 4, 519-537. doi: 10.1007/s12571-0120200-5

Sharon, A., and Shlezinger, N. (2013). Fungi infecting plants and animals: killers, non-killers, and cell death. PLoS Pathog. 9:e1003517. doi: 10.1371/journal.ppat. 1003517

Sierotzki, H., Wullschleger, J., and Gisi, U. (2000). Point mutation in cytochrome $\mathrm{b}$ gene conferring resistance to strobilurin fungicides in Erysiphe graminis $\mathrm{f} . \mathrm{sp}$. tritici field isolates. Pestic. Biochem. Physiol. 68, 107-112. doi: 10.1006/pest.2000. 2506

Snelders, E., Camps, S. M. T., Karawajczyk, A., Schaftenaar, G., Kema, G. H. J., van der Lee, H. A., et al. (2012). Triazole fungicides can induce cross-resistance to medical triazoles in Aspergillus fumigatus. PLoS ONE 7:e31801. doi: 10.1371/ journal.pone.0031801

Soanes, D., and Richards, T. A. (2014). Horizontal gene transfer in eukaryotic plant pathogens. Annu. Rev. Phytopathol. 52, 583-614. doi: 10.1146/annurev-phyto102313-050127

Soler-Hurtado, M. M., Sandoval-Sierra, J. V., Machordom, A., and DiéguezUribeondo, J. (2016). Aspergillus sydowii and other potential fungal pathogens in Gorgonian Octocorals of the Ecuadorian Pacific. PLoS ONE 11:e0165992. doi: 10.1371/journal.pone.0165992

Srikanta, D., Santiago-Tirado, F. H., and Doering, T. L. (2014). Cryptococcus neoformans: historical curiosity to modern pathogen. Yeast 31, 47-60. doi: $10.1002 /$ yea.2997

Stanley, M. S., Callow, M. E., Perry, R., Alberte, R. S., Smith, R., and Callow, J. A. (2002). Inhibition of fungal spore adhesion by zosteric acid as the basis for a novel, nontoxic crop protection technology. Phytopathology 92, 378-383. doi: 10.1094/PHYTO.2002.92.4.378

Taweechaisupapong, S., Singhara, S., Lertsatitthanakorn, P., and Khunkitti, W. (2010). Antimicrobial effects of Boesenbergia pandurata and Piper sarmentosum leaf extracts on planktonic cells and biofilm of oral pathogens. Pak. J. Pharm. Sci. $23,224-231$.

Theodorakopoulos, N., Govetto, B., Industri, B., Massi, L., Gaysinski, M., Deleury, E., et al. (2011). Biology and ecology of biofilms formed by a plant pathogen Phytophthora parasitica: from biochemical ecology to ecological engineering. Procedia Environ. Sci. 9, 178-182. doi: 10.1016/j.proenv.2011. 11.027

Tsang, P. W. K., Bandara, H. M. H. N., and Fong, W. P. (2012). Purpurin suppresses Candida albicans biofilm formation and hyphal development. PLoS ONE 7:e50866. doi: 10.1371/journal.pone.0050866

Van Acker, H., Van Dijck, P., and Coenye, T. (2014). Molecular mechanisms of antimicrobial tolerance and resistance in bacterial and fungal biofilms. Trends Microbiol. 22, 326-333. doi: 10.1016/j.tim.2014. 02.001

Verweij, P. E., Snelders, E., Kema, G. H., Mellado, E., and Melchers, W. J. (2009). Azole resistance in Aspergillus fumigatus: a side-effect of environmental fungicide use? Lancet Infect. Dis. 9, 789-795. doi: 10.1016/S1473-3099(09) 70265-8

Villa, F., Albanese, D., Giussani, B., Stewart, P. S., Daffonchio, D., and Cappitelli, F. (2010). Hindering biofilm formation with zosteric acid. Biofouling 26, 739-752. doi: 10.1080/08927014.2010.511197

Villa, F., Borgonovo, G., Cappitelli, F., Giussani, B., and Bassoli, A. (2013a). Sublethal concentrations of Muscari comosum bulb extract suppress adhesion and induce detachment of sessile yeast cells. Biofouling 28, 1107-1117. doi: 10.1080/ 08927014.2012.734811

Villa, F., and Cappitelli, F. (2013). Plant-derived bioactive compounds at sub-lethal concentrations: towards smart biocide-free antibiofilm strategies. Phytochem. Rev. 12, 245-254. doi: 10.1007/s11101-013-9286-4

Villa, F., Pitts, B., Stewart, P. S., Giussani, B., Roncoroni, S., Albanese, D., et al. (2011). Efficacy of zosteric acid sodium salt on the yeast biofilm model Candida albicans. Microb. Ecol. 62, 584-598. doi: 10.1007/s00248-0119876-x 
Villa, F., Remelli, W., Forlani, F., Vitali, A., and Cappitelli, F. (2012). Altered expression level of Escherichia coli proteins in response to treatment with the antifouling agent zosteric acid sodium salt. Environ. Microbiol. 14, 1753-1761. doi: 10.1111/j.1462-2920.2011.02678.x

Villa, F., Villa, S., Gelain, A., and Cappitelli, F. (2013b). Sub-lethal activity of small molecules from natural sources and their synthetic derivatives against biofilm forming nosocomial pathogens. Curr. Top. Med. Chem. 13, 3184-3204.

Żukiewicz-Sobczak, W. A. (2013). The role of fungi in allergic diseases. Postepy Dermatol. Alergol. 30, 42-45. doi: 10.5114/pdia.2013.33377
Conflict of Interest Statement: The authors declare that the research was conducted in the absence of any commercial or financial relationships that could be construed as a potential conflict of interest.

Copyright $@ 2017$ Villa, Cappitelli, Cortesi and Kunova. This is an open-access article distributed under the terms of the Creative Commons Attribution License (CC BY). The use, distribution or reproduction in other forums is permitted, provided the original author(s) or licensor are credited and that the original publication in this journal is cited, in accordance with accepted academic practice. No use, distribution or reproduction is permitted which does not comply with these terms. 